\title{
Tensions of Empire
}





\section{Tensions of Empire}

Colonial Cultures in a Bourgeois World

Frederick Cooper by
Ann Laura Stoler 
University of California Press

Berkeley and Los Angeles, California

University of California Press

London, England

Copyright $\odot 1997$ by The Regents of the University of California

Library of Congress Cataloging-in-Publication Data

Tensions of empire : colonial cultures in a bourgeois world / edited

by Frederick Cooper, Ann Laura Stoler.

p. $\mathrm{cm}$.

Includes bibliographical references and index.

ISBN 978-0-520-20605-2 (pbk. : alk. paper)

I. History, Modern-I9th century. 2. History, Modern-2oth century. 3. Imperialism-HistoryI9th century. 4. Imperialism-History-2oth century. 5. Europe-History-1789-1900.

6. Europe-History-2oth century. 7. Colonies.

I. Cooper, Frederick, I947-. II. Stoler, Ann Laura.

D359.T4 1997

909.8- dc20

96-32968

CIP

Printed in the United States of America
I7 I6 I5 I4 I3 I2 II
I5 I4 I3 I2 II IO 9

The paper used in this publication meets the minimum requirements of ANSI/NISO Z39.48-I992 (R I997)

(Permanence of Paper). @ 